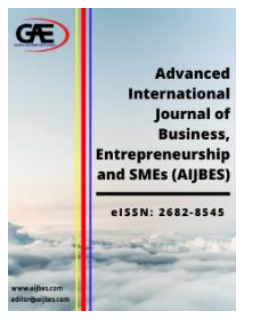

\author{
ADVANCED INTERNATIONAL JOURNAL OF \\ BUSINESS, ENTREPRENEURSHIP AND SMES \\ (AIJBES) \\ www.aijbes.com
}

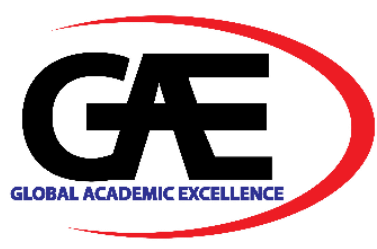

\title{
BUSINESS SIMULATION AS KEY MOTIVATION FACTOR IN STIMULATING BUSINESS INTENTION AMONGST UNIVERSITY STUDENTS IN MALAYSIA
}

\author{
Mohd Sufli Yusof $^{1 *}$ \\ 1 School of Business Management, Universiti Utara Malaysia, Malaysia \\ Email: mohdsufli@uum.edu.my \\ Corresponding Author
}

\section{Article Info:}

Article history:

Received date: 01.12.2021

Revised date: 15.12 .2021

Accepted date: 25.12 .2021

Published date: 30.12 .2021

To cite this document:

Yusof, M. S. (2021). Business Simulation As Key Motivation Factor In Stimulating Business Intention Amongst University Students In Malaysia. Advanced International Journal of Business, Entrepreneurship and SMEs, 3 (10), 69-74.

DOI: $10.35631 / A I J B E S .310006$.

This work is licensed under CC BY 4.0 (c) (2)

\begin{abstract}
:
The importance to raise up the number of entrepreneurs among the younger generation, especially among the university's students has been recognized by the Government. This study seeks to link the effectiveness of business simulation with entrepreneurship interest of the students in University Utara Malaysia, main campus, Sintok. Four main objectives of the study were highlighted which is to see the relationship of perception, learning, interest and satisfaction of the business simulation on the tendency of students to venture into the business environment. The fifth objective is the combination of perception, learning, interest and satisfaction from business simulations of their entrepreneurial tendencies. The findings show that there is a significant relationship between learning, interest, satisfaction and the combination of all dimensions-dimensions of the business tendency. The findings from this study particularly useful to certain parties in the field of education and also to entrepreneurial developers.
\end{abstract}

Keywords:

Business Simulation, Business Intention, Entrepreneurship, Effectiveness, Universiti Utara Malaysia

\section{Introduction}

Entrepreneurship education is commonly perceived as the process of training individuals to be able to recognize commercial opportunities and the insight, knowledge and related skills to act on them through the formation of a business venture (Abdul Majid, Ismail, \& Aman, 2010). However, there is an ongoing debate about whether or not we can actually teach students to be entrepreneurs (Fiet, 2000). This argument is also suggested to originate from the suspicion on 
Volume 3 Issue 10 (December 2021) PP. 69-74 DOI 10.35631/AIJBES.310006

whether entrepreneurs are born or made.Gordon and Howell (1959) were the first to realize what is learned as an undergraduate, and what prospective employers expect business students to know upon graduation were not congruent. Subsequent research from the 1970s through 2015 (Mintzberg, 1975); Mandt, (1982). Mullin, Shaffer, \& Grelle, 1991; Fabris 2015 further confirmed the lack of preparedness by students graduating from bachelor's programs in business.

Finding by Cheng, Chan \& Mahmood (2009), showed the ineffectiveness of entrepreneurship education in Malaysia in matching students' skill expectations with their skill acquisition. Teaching methods in entrepreneurship courses in Malaysia is commonly used lectures $(84.4 \%)$ as compared to other interactive methods such as case studies (11.5\%), invited guest speakers $(6.3 \%)$, role play (11.5\%) and business simulations $(12.5 \%)$. The topic of simulation and entrepreneurship education was well reviewed in a series of articles in Simulation and Gaming, guest edited by Karz, Low, and Starr (1994,1996). In one insightful empirical study in this series, Low, Venkataraman, and Srivatsan (1994) attempted to develop a simulation that would be both pedagogically useful and provide a theoretical-research perspective. They found these two goals to be mutually exclusive.

This suggest that considerable research is necessary to explore both ends of the equation - how much students learn, and separately, whether what they learn is relevant. Other studies apppear to demonstrate effective and applied learning, in terms of application of stereotype formation, resulting from simulation activities.

\section{Literature Review}

\section{Business Simulation}

Garris et al. (2002) process domain describes a basic motivational mechanism to foster continuous and motivated virtual/game playing, which enables and reinforces learning. According to the model, the game cycle is triggered through the successful pairing of instructional content and game characteristics, leading to loops of judgement-behaviorfeedback that promotes learning. This mechanism incorporates the fundamental driving force for students to repeatedly play the game, a relevant factor to promote virtual/game playing. Therefore, other variables and processes are incorporated into the new design model to offer a more comprehensive and holistic view of the intricate learning process derived from simulation virtual/game playing. These variables range from level of participation to quality of instruction to level of satisfaction.

Motivation can either be intrinsic or extrinsic to the student. Intrinsic motivation is the student's desire to perform the activity because the activity is interesting in itself; whereas extrinsic motivation is the drive to perform the activity because achieving an outcome is important and rewarding (Garriss et al., 2002). Whether intrinsic or extrinsic, the student's own motivation to play the game is expected to strongly impact learning. The intention is for the students to be able to apply knowledge in the future based on understanding and perception of business processes they have self-experienced; in other words, the "whole idea is to give the participants knowledge that can be transferred to environments beyond the learning situation" later on (Lainema, 2008). 


\section{Business Intention}

Business simulation provided a good learning experience and helped students developed some required business skills and gain an understanding of the value of team work (Fregetto, 2006). However, the question is whether students are inclined entrepreneurially or intend to start business after attending a business simulation game. This is an important question for entrepreneurship courses if the course is open for general enrollment as an elective, because the course will generally have a significant number of students who do not aspire to be an entrepreneur.

Instead, these students may only require the credits as electives in order to graduate or simply have a general interest in knowing about entrepreneurship without having any genuine intention to become an entrepreneur. One practical application of this study will be to identify whether different teaching methods are needed depending on the student's business intentions.

\section{Research Framework}

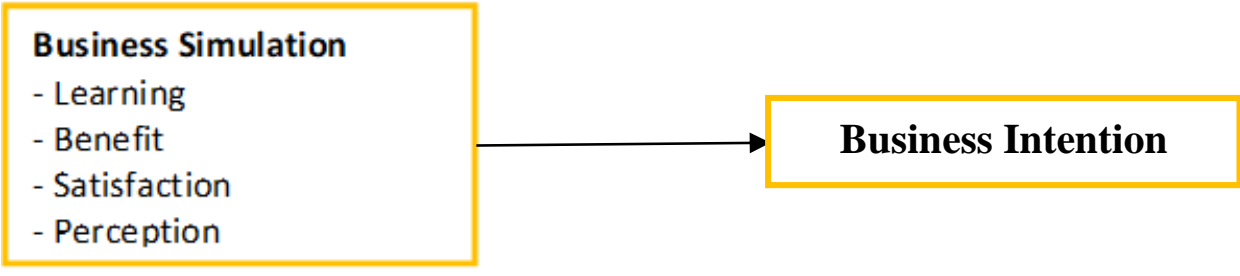

Figure 1: Research Framework

\section{Research Methodology}

\section{Procedures and Sample}

In this study the quantitative research design is used as it is a systematic and scientific for identifying associations and interaction between different variables under study. Students from Introduction to Entrepreneurship Course were chosen to be the population for this research. About 500 students were explained about the process of simulation as the learning process for entrepreneurship education. Discussion about the method was carried out to ensure the students really understand about this approach of entrepreneurship teaching and learning process. About 350 students were randomly selected to answer the questionnaires but only 160 questionnaires were used for analysis since the others were not completed. The response rate is $45.7 \%$.

\section{Questionnaires}

This study adapted questionnaire from Michael Sorensen (2010), Learning with Simulation Games, Copenhagen Business School. The questionnaire consist of three sections. Section A, consist of 14 items on personal background and 5 items on readiness to become entrepreneurs. Section B, consist of 4 variables of learning, benefit, satisfaction and perception of business simulation with total of 32 items. While section $\mathrm{C}$ is on the business intention with 5 items. The questionnaire based on measurement in this study which was developed for collecting the student's response of concerning to their perception on effectiveness of simulation, leading to business intentions. 


\section{Data Analysis}

\section{Multiple Regression Analysis}

Multiple regression analysis was conducted to find out the predictive power of the independent variables (Learning, Benefit, Satisfaction and Perception) towards the dependent variable (Business Intention). Before conducting multiple regression analysis all the assumptions of performing multiple regression analysis such as normality, linearity, homoscedasticity, autocorrelation and multicollinearity were satisfied.

Multiple regression analysis was conducted in order to test the hypothesis H1-H5. Multiple regression analysis elaborates the predictive power of independent variables (Learning, Benefit, Satisfaction and Perception) towards the dependent variable (Business Intention). The coefficient of determination $\mathrm{R}^{2}$ value elaborates the goodness of model fit. As per recommendations put forwards by Cohen (1988), $\mathrm{R}^{2}$ value of 0.02 refers to poor model fit or weak contribution of the model, $\mathrm{R}^{2}$ value of 0.13 is regarded as a medium or moderate level of model fit, and $\mathrm{R}^{2}$ value of 0.26 and above refers to sizeable and significant contribution of the model or in other words it indicates higher level of model fit.

Table 1: Analysis Result

\begin{tabular}{|c|c|c|c|c|c|c|c|c|}
\hline Variables & $\begin{array}{l}\text { Standard } \\
\text { Coeff. } \\
\text { (Beta) }\end{array}$ & $\begin{array}{l}\mathrm{T} \\
\text { Value }\end{array}$ & $\begin{array}{l}\mathrm{P} \\
\text { Value }\end{array}$ & $\begin{array}{l}\mathrm{R} \\
\text { Square }\end{array}$ & $\begin{array}{l}\text { Adjusted } \\
\text { R Square }\end{array}$ & $\begin{array}{l}\text { F } \\
\text { Value }\end{array}$ & $\begin{array}{l}\text { F } \\
\text { Value } \\
\text { Sig } \\
\end{array}$ & $\begin{array}{l}\text { Durbin- } \\
\text { Watson }\end{array}$ \\
\hline Learning & -0.637 & -10.347 & 0.000 & 0.405 & 0.402 & $\begin{array}{l}107.0 \\
70\end{array}$ & 0.000 & 1.792 \\
\hline Benefit & 0.602 & 9.439 & 0.000 & 0.362 & 0.358 & $\begin{array}{l}89.08 \\
6\end{array}$ & 0.000 & 2.320 \\
\hline Satisfaction & 0.799 & 16.630 & 0.000 & 0.638 & 0.636 & $\begin{array}{l}276.5 \\
44\end{array}$ & 0.000 & 2.364 \\
\hline Perception & 0.103 & 1.302 & 0.195 & 0.011 & 0.004 & 1.695 & 0.195 & 2.130 \\
\hline $\begin{array}{l}\text { Learning, } \\
\text { Benefit, } \\
\text { Satisfaction } \\
\text { and } \\
\text { Perception }\end{array}$ & $\begin{array}{l}-0.978 \\
-0.662 \\
0.982 \\
-0.575\end{array}$ & $\begin{array}{l}-30.555 \\
-18.739 \\
34.570 \\
-21.388\end{array}$ & $\begin{array}{l}0.000 \\
0.000 \\
0.000 \\
0.000\end{array}$ & 0.949 & 0.947 & $\begin{array}{l}713.6 \\
17\end{array}$ & 0.000 & 2.500 \\
\hline
\end{tabular}

Table 2: Result Summary

\begin{tabular}{lll}
\hline Hypotheses & Description & Result \\
\hline H1 & $\begin{array}{l}\text { There is a significant relationship between Learning Business } \\
\text { Simulation and Business Intention. }\end{array}$ & Accepted \\
\hline H2 & $\begin{array}{l}\text { There is a significant relationship between Benefit of Business } \\
\text { Simulation and Business Intention }\end{array}$ & Accepted \\
\hline H3 & $\begin{array}{l}\text { There is a significant relationship between Satisfaction of } \\
\text { Business Simulation and Business Intention. }\end{array}$ & \\
\hline H4 & $\begin{array}{l}\text { There is a significant relationship between Perception of } \\
\text { Business Simulation and Business Intention. }\end{array}$ & \\
& &
\end{tabular}


Volume 3 Issue 10 (December 2021) PP. 69-74 DOI 10.35631/AIJBES.310006

H5 There is a significant relationship between Learning, Benefit, Accepted Satisfaction, Perception of Business Simulation and Business Intention

\section{Conclusion and Discussion}

This study focuses on the role of business simulation as a method or an approach to generate excitement and enthusiasm of a student towards entrepreneurship. It stems from the marketability of graduates in the real world industry challenges. The students hope that they will gain knowledge corresponding to what the industry when they stepped out of from higher learning institutions. Similarly, the industry requires a workforce that no longer needs to be trained in order to save time, money and so on. The gap is quite wide as teaching and learning system provided in universities are still conventional in shaped. Teaching and learning are still in the form of lectures, classes, invited lectures, case studies, examination-oriented and so on which have less exposure to the real industry.

Therefore, this study was undertaken in an effort to determine the influence or relations between teaching methods through the business simulation with business interests among students in universities, especially in UUM. In literature review, business simulation methods have been found to have a large role in influencing a person's interest in becoming entrepreneurs.

\section{References}

Abdul Majid, I, Ismail, K., \& Aman, O. (2010). Exploring entrepreneurship training in Malaysia's public higher Learning Institution, International Conference In Business Management (ICBM), Bangkok.

Cheng, M. Y., Chan, W. S., \& Mahmood, A. (2009). The effectiveness of entrepreneurship education in Malaysia.

Cohen, J. (1988). Statistical power analysis for the behavioral sciences. Second Edition. Hillsdale, NJ: Lawrence Erlbaum Associates, Publishers.

European Commission (2008). Entrepreneurship in higher education, especially within nonbusiness studies (Final Report). European Union: Directorate-General for Enterprise and Industry.

Fabris, C, (2015). College students feel prepared for jobs. Employer's aren't so sure. Chronicle for Higher Education, 6/(20), A10-A11. Retrieved from http://chronicle .com

.Fiet, J.O. (2000). The theoretical side of teaching entrepreneurship theory. Journal of Business Venturing, 16(1), 1-24.

Garis, R. Ahlers, R., \& Driskel. J.E. (2002). Games, motivation, and learning: A research and practive model. Simulation \& Gaming, 33(4), 441-67.

Gordon, R. \& Howell, J. (1959). Higher Education fo Business. New York, N.Y: Garland.

Gosen, J. \& Washbush, J. (2004). A review of schlorship on assessing experiential learning effectiveness. Simulation \& Gaming, 35(2), 270-293.

Karz, J., Gundry, L., Low, M., \& Starr, J. (1994). Guest editorial: Simulation and experiential learning in entrepreneurship education. Simulation and Gaming, 25, 335-337.

Karz, J., Gundry, L., Low, M., \& Starr, J. (1995). Guest editorial: Simulation and experiential learning in entrepreneurship education. Simulation and Gaming, 26, 286-287.

Karz, J., Gundry, L., Low, M., \& Starr, J. (1996). Guest editorial: Simulation and experiential learning in entrepreneurship education. Simulation and Gaming, 27, 332-333.

Lainema, T. \& Makkonen, P. (2003). Applying constructivist approach to educational business games: case REALGAME. Simulation \& Gaming, 34(1), 131. 
Volume 3 Issue 10 (December 2021) PP. 69-74 DOI 10.35631/AIJBES.310006

Lainema, T. (2008). Perspective making: Constructivism as a meaning -making structure for simulation game. 29.

Low, M., Venkataraman, S.M \& Srivatsan, V. (1994). Developing an entrepreneurship game for teaching and research. Simulation and Gaming, 25, 383-401.

Mandt, E (1982). The failure of business education - and what to do about it. Management Review, 71, 47-52. Retriieved from http://aom.org/amr.

Mintzberg, H. (1975), The manager's job: Folklore and Fact. Harvard Business Review, 53, 49-71. Retrieved from https:/hbr.org.

Mullin,R., Shaffer, P. \& Grelle (1991) A study of the assessment center method of teaching basic management skills. In J.d. Bigelow (Ed.). Management Skills Exploration in Practical Knowledge, 116-139Thousand Oaks, CA: Sage

Sorensen, M. (2010). Evaluating hotel simulation games' effectiveness on higher academic performance within service and hospitality, Master Thesis, Copenhagen Business School, Copenhagen. 